CONFERENCE REPORT

\title{
A breath of fresh air? Report of the 2003 British Thoracic Society Winter Meeting
}

\author{
J R Hurst, B S W Choo-Kang
}

Thorax 2004;59:190-193. doi: 10.1136/thx.2003.019968

An overview of some of the key topics presented at the BTS Winter Meeting held in London on 3-5 December 2003.

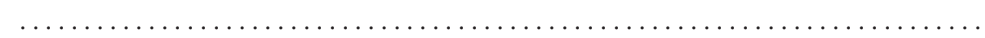

U pon us again, and somehow December wouldn't be December without the annual trip to London for the British Thoracic Society (BTS) Winter Meeting. This year 1600 delegates attended 13 symposia and 309 abstract presentations at which invited speakers, clinicians and researchers reported and discussed a broad range of studies. In this report we link themes developed in the major symposia to abstracts presented in the spoken and poster sessions.

\section{INFECTION}

Infection featured prominently at the meeting with symposia on tuberculosis (TB), pneumococcal disease, a joint BTS/BPRS session on empyema and-a sign of changing times-a full day assembly on bioterrorism. To a hushed auditorium at the empyema symposium, Dr Davies presented the important, surprising, and negative results of the 3 month MIST trial on the role of streptokinase in empyema.

Dr Moore-Gillon delivered the 2003 Snell Memorial Lecture on TB, a topic which also featured in the "Highlights of respiratory science" symposium with a presentation by Dr Lalvani on a novel peripheral blood $\mathrm{T}$ cell approach to diagnosis. A common theme of "prospects for future care in $\mathrm{TB}^{\prime}$ emerged, contrasting with the difficult decisions we are currently forced to make as a consequence of present diagnostic and therapeutic inadequacies. Unsurprisingly then, improving current outcomes with limited resources was the subject of many abstracts including studies on patient read Heaf tests ${ }^{1}$ and rapid genetic approaches to drug resistance testing. ${ }^{2}{ }^{3}$ Ormerod and colleagues reported their extensive experience with extrapulmonary TB. ${ }^{45}$ While it was reassuring to hear results from a national treatment study that around $80 \%$ of cases complete treatment ${ }^{6}$ and, given the rising prevalence of TB/HIV co-infection, a report of good clinical outcomes using combination therapy, ${ }^{7}$ we were reminded of the relatively high prevalence of $\mathrm{TB}$ in healthcare workers. $^{8}$

Cystic fibrosis (CF) remains an active field of research and abstracts included an analysis of viral exacerbations ${ }^{9}$ and a promising report on the use of Sendai virus to transfect the CF transmembrane regulator gene in both in vitro and in vivo model systems. ${ }^{10}$ A recent paper suggesting that the association between CF related diabetes and decline in lung function may relate to glucose in airway secretions was taken further with a study investigating nasal glucose concentrations in CF. ${ }^{11}$ Dr De Soyza won the BLF Young Investigator's Prize for his work on the different phenotypes of Burkholderia cepacia isolated from patients with $\mathrm{CF}$ and chronic granulomatous disease. ${ }^{12}$

\section{ASTHMA}

Asthma continues to be well represented with symposia held on the BTS/SIGN guidelines, inflammatory-structural cell interactions and a third, held jointly with the BSACI, focusing on immunoglobulin E. Professor Lee delivered the 2003 Altounyan lecture entitled "Glucocorticoids, regulatory T cells and bronchial asthma", the BTS medal was awarded to Professor Howell in recognition of his work on hyperventilation syndromes and cromoglycate, and Dr Baker won the BTS Young Investigator's Prize for her work exploring the drug-receptor interactions of $\beta_{2}$ adrenoceptor agonists ${ }^{13}$ against impressive competition from the five other short listed researchers. ${ }^{12}{ }^{14-17}$

Interest in paediatric disease was high, including a report that the prevalence of asthma symptoms appears to vary between ethnic groups-being lower in Asian families, perhaps because of differences in household smoking habits. ${ }^{18}$ In younger children, classifying respiratory symptoms from parents' descriptions can be difficult but Saglani et al showed how video demonstrations of wheeze, stridor, and upper airway sounds can improve accuracy. ${ }^{19}$ While morbidity from asthma is increasing, mortality is falling and a review of deaths in children aged 1-16 years in England and Wales between 1968 and 2000 showed that the proportion due to respiratory diseases has fallen from $17.3 \%$ to $8 \% .^{20}$

This year's scientific sessions placed much emphasis on structural pathology such as airway remodelling and smooth muscle biology. Studies using endobronchial ultrasound to assess airway wall thickness showed that increasing wall thickness correlates with decreasing hyperresponsiveness, contrary to mathematical models. ${ }^{21} 22$ Transforming growth factor (TGF)- $\beta$ may have an important role in airway remodelling, as indicated by a report showing that anti-TGF- $\beta_{1}$ antibodies reduced subepithelial collagen deposition in a murine model. ${ }^{23}$

Possibly the most controversial presentation of the meeting was a randomised controlled trial of the Buteyko breathing method in asthma which 
reported improvements of up to $98 \%$ in symptoms and use of reliever medication. ${ }^{24}$ These results were met with scepticism by some members of the audience, particularly as details on patient characteristics, pulmonary function tests, and outcome measures were not available. Many patients who improve with breathing methods have hyperventilation syndrome as well as-or instead of-asthma. Stirrat and co-workers reported that such patients have a heightened perception of breathlessness at given airway resistances compared with normal subjects. ${ }^{25}$ Psychosocial factors also have a significant impact in asthma, particularly in chronic or severe disease, and Highfield et al reported that this is less so for patients with type 2 brittle asthma than for other severe asthma phenotypes. ${ }^{26}$

The neglected area of occupational asthma made the BBC news with a report of a study in bakers presented at the meeting which suggested that cough is the initial symptom experienced by these patients. ${ }^{27}$

\section{ONCOLOGY}

Cancer topics featured at the "Imaging" and "Thoracic Oncology" symposia. While Dr Rudd reviewed the role of novel agents such as growth factor inhibitors, current treatment too often remains palliative and the themes of earlier and more accurate diagnosis emerged. Dr Gleeson highlighted the crucial role of the radiology department and encouraged units to audit their incidence of retrospectively missed diagnoses. Experience from a unit in Northern Ireland suggests a frequency of $10 \%{ }^{28}$ Computer assisted nodule detection algorithms were reported as one approach to improving detection rates. ${ }^{29}$ Once patients are referred, two reports suggested that symptoms at presentation are unhelpful in determining who does and does not have cancer. ${ }^{30} 31$ Regarding investigation, the use of initial CT scanning may reduce the number of bronchoscopies required. ${ }^{32}$ Ultrasound based biopsy of peripheral lesions is a cost effective alternative to CT scanning, and a group from Glasgow reported their experience of this technique performed by chest physicians rather than radiologists. ${ }^{33}$ Elsewhere, the superiority of Trucut over Abrams' biopsy was described, even without radiological guidance. ${ }^{34}$ Developments to improve staging accuracy included ultrasound scanning of the neck with aspiration of enlarged nodes to detect stage IV disease, ${ }^{35}$ and the addition of endobronchial ultrasound to enhance transbronchial needle aspiration (TBNA) of mediastinal lesions. ${ }^{36}$ West and Slade reported the safety and utility of TBNA in the absence of formal training. ${ }^{37}$ While new staging techniques such as CT-PET are not yet widely available, one group reported their experience with routine head CT scans in patients with potentially resectable non-small cell disease, $4.8 \%$ of patients having unanticipated cerebral metastases. ${ }^{38}$ Once a diagnosis has been made, it was disappointing to be reminded that surgical patients are still not meeting NHS Cancer Plan waiting time targets, ${ }^{39}$ and that there are ongoing problems with access to specialist oncology services. $^{40}$ A group from Liverpool reminded us that it is performance status and not age that should guide decisions on chemoradiotherapy, ${ }^{41}$ and the same authors described their experience with the rare but important diagnosis of synchronous primary tumours. ${ }^{42}$

\section{CHRONIC OBSTRUCTIVE PULMONARY DISEASE (COPD)}

The only symposium to feature COPD this year focused on oxygen and, in particular, oxidative stress. In support of the importance of oxidative stress, an epidemiological study reported an association between low plasma vitamin $\mathrm{C}$ levels and faster lung function decline in smokers. ${ }^{43}$ Progression of disease increases COPD morbidity and a group from
Birmingham reported their experience in the search for a marker associated with faster decline. ${ }^{44} \mathrm{CT}$ densitometry was also reported as useful in monitoring disease progression. ${ }^{45}$ Exacerbations contribute to lung function decline and there is considerable interest in modelling these events. Mallia and colleagues reported their pilot experience of experimental rhinovirus exacerbations, ${ }^{46}$ while Allenby et al described inhaled lipopolysaccharide as a practical and safe stimulus to model neutrophilic airway inflammation. ${ }^{47} 48$

No major therapeutic developments were discussed, but the benefits of early treatment of exacerbations were reported. ${ }^{49}$ Given the limitations of current treatment, it was disappointing to learn that facilities for smoking cessation, non-invasive ventilation (NIV), and pulmonary rehabilitation are still inadequate. ${ }^{50-52}$ Effective provision of NIV services is dependent on staff training and deficiencies in the provision of this were noted by Sander and Mak. ${ }^{53}$ Smoking cessation must remain a major strategy, a point emphasised by Sir Richard Peto in the Morriston Davies lecture.

\section{SLEEP AND RESPIRATORY MUSCLES}

A joint BTS/BPRS symposium on sleep medicine covered a variety of topics. Patients with obstructive sleep apnoea (OSA) and residual sleepiness despite treatment with continuous positive airway pressure (CPAP) are a challenging problem. The Modafinil OSA Study Group reported a long term trial of modafinil and showed significant improvement in both Epworth and quality of life scores. ${ }^{54}$ Another study looked at mortality in patients with OSA. ${ }^{55}$ Interestingly, women with OSA were found to be more than twice as likely as men to die, perhaps because the women had a higher average body mass index and were therefore at increased risk of cardiovascular co-morbidity. Sleep disordered breathing (SDB) is increasingly recognised in patients with heart failure, and two reports showed that patients with mild heart failure and SDB had fewer symptoms, ${ }^{56}$ and their sleep studies showed less nightly variation than patients with OSA. ${ }^{57}$

Relationships between muscle function, sleep, and breathing are an increasingly important aspect of respiratory medicine, and an excellent poster discussion session reflected the breadth of interest in this area. Interrelationships between stroke and breathing were reported in several abstracts: a study of almost 2000 men in Caerphilly showed that sleep disorders were associated with an increased risk of stroke, ${ }^{58}$ whereas those patients who have already had a stroke experience a high incidence of OSA.99 Post-stroke patients have demonstrably impaired respiratory muscle function, more so in those who aspirate. ${ }^{60}$ Domiciliary NIV is increasingly used for children with muscular disease. Kinali et al reported that over $80 \%$ of responding specialists discussed this option with their patients, although the group surveyed did not include more general respiratory paediatricians. ${ }^{61}$ Patients on home NIV are susceptible to respiratory infections and it was reassuring to see a report that the range of pathogens in such patients was similar to those in COPD rather than community acquired pneumonia. ${ }^{62}$ Finally, in addition to muscle disease causing respiratory disability, respiratory disease may itself cause muscle weakness and two abstracts looked at this phenomenon. The first reported that the $\mathrm{D}$ allele of the angiotensin converting enzyme (ACE) gene was associated with increased quadriceps strength in $\mathrm{COPD}^{63}$-although what this means clinically and any effect of ACE inhibitors remains unclear. The second reported that supplementation of diet with creatine-used within the athletic community-increased fat free mass, muscle strength, and quality of life in COPD patients when combined with pulmonary rehabilitation. ${ }^{64}$ 


\section{INTERSTITIAL LUNG DISEASE AND TRANSPLANTATION}

Relatively under-represented at the meeting, interstitial lung disease was discussed at just one session which provided a pot pourri of subjects. Hayee and colleagues reported a study of pulmonary function testing (PFT) in patients undergoing treatment with methotrexate for connective tissue diseases. ${ }^{65}$ This supported the view that routine monitoring of PFTs is not useful, but the authors did find a high proportion of patients with at least one abnormal baseline result. Elsewhere, Ismail et al showed that the incidence of immune sensitisation in pigeon fanciers has increased over a 12 year period. ${ }^{66}$ One of the few presentations on lung transplantation suggested that 10 year survivors have good functional status, although a significant number require renal replacement therapy. ${ }^{67}$ Finally, Ho and co-workers reported an intriguing deficiency of immunoregulatory natural killer $\mathrm{T}$ cells in the blood and bronchoalveolar lavage fluid of patients with sarcoidosis. ${ }^{68}$

\section{AND FINALLY...}

As always, the BTS Winter Meeting provided an impressive combination of basic and clinical science that is crucial to the future of our specialty. There are, however, considerable current problems in funding respiratory research, an issue that was highlighted at the BLF Lung Research symposium. ${ }^{69}$ While some diseases are funded predominantly by charitable, governmental, or pharmaceutical sources, others have no obvious financial support and crucially these funding patterns do not follow disease burden. Finally-and an appropriate note on which to end-we report the message of the BTS President, Professor Stephen Spiro, in his presidential address. He emphasised the need for each and every one of us to raise the profile of respiratory medicine for the future benefit of all our patients. We couldn't agree more.

\section{Authors' affiliations}

J R Hurst, Academic Unit of Respiratory Medicine, St Bartholomew's Hospital, London EC1A 7BE, UK

B S W Choo-Kang, Department of Respiratory Medicine, Glasgow Royal Infirmary, Glasgow G31 2ER, UK

\section{REFERENCES}

1 Bullen J, Swallow EB. A novel approach to Heaf test reading. Thorax 2003;58(Suppl III):iii56-7 (abstract P58).

2 Baker LV, Brown TJ, Yates MD, et al. Rapid detection of resistance to other first line drugs in rifampicin resistant tuberculosis. Thorax 2003;58(Suppl III):iii55 (abstract P52).

3 Baker LV, Brown TJ, Yates MD, et al. Sequencing of the PNCA gene provides a rapid means of detecting pyrazinamide resistance in multidrug resistant tuberculosis (MDRTB). Thorax 2003;58(Suppl III):iii55 (abstract P53).

4 Ormerod LP, Ramesh J, Banait GS, et al. Gastrointestinal tuberculosis: Blackburn 1985-2002. Clinical features and management. Thorax 2003:58(Suppl III):iii57 (abstract P59).

5 Ormerod LP, Sandher DA, Al-Jibury M, et al. Bone and joint tuberculosis: Blackburn 1988-2002. Clinical features and management. Thorax 2003:58(Suppl III):iii57 (abstract P60).

6 Antoine D, Akhtar $M$, Jones JA, et al. Tuberculosis treatment outcome monitoring: first national results. Thorax 2003;58(Suppl III):iii40 (abstract S134)

7 Breen R, Swaden L, Ballinger J, et al. Treatment of HIV/TB in the era of HAART. Thorax 2003;58(Suppl III):iii40 (abstract S132).

8 Ho TBL, Lindfield T, Whiffield R, et al. Prevalence of tuberculosis among healthcare workers: a retrospective analysis. Thorax 2003;58/Suppl III): iiii0-41 (abstract S135).

9 McManus TE, Christie SN, Magorrian B, et al. Respiratory viral infections in childhood exacerbations of cystic fibrosis. Thorax 2003;58(Suppl III):iii63-64 (abstract P85).

10 Ferrari S, Griesenbach U, Farley R, et al. Recombinant Sendai virus mediates CFTR gene transfer to airway epithelium both ex vivo and in vivo. Thorax 2003;58(Suppl III):iii 19-20 (abstract S61).

11 Brennan AL, Geddes DG, Hodson ME, et al. 24 hour glucose monitoring and nasal glucose measurement in patients with cystic fibrosis. Thorax 2003;58(Suppl III):iii19 (abstract S59).
12 De Soyza A, Morris K, Perry J, et al. Divergent pro-inflammatory activity of B cepacia complex strains dependent on patient diagnosis: cystic fibrosis vs chronic granulomatous disease. Thorax 2003;58(Suppl III):iii2 (abstract T5).

13 Baker JG. Hill SL. Salmeterol, a long acting agonist stimulates more cyclic AMP-mediated gene transcription than the short-acting agonist isoprenaline. Thorax 2003;58(Suppl III):iiil (abstract T1).

14 Callister MEJ, Pinhu L, Finney SJ, et al. Inhibition of intracellular thioredoxin activity prevents inflammatory activation of an alveolar epithelial cell line through effects on the nuclear factor- $\kappa B$ signaling pathway. Thorax 2003;58(Suppl III):iiil (abstract T2).

15 Carroll WD, Fryer AA, Child $F$, et al. Further evidence supporting an in utero effect of maternal GSPT1 on asthma phenotype. Thorax 2003;58(Suppl III):iiil-2 (abstract T3).

16 Clayton A, Holland E, Pang LH, et al. Interleukin-1- $\beta$ (IL-1 $\beta$ ) reduces cyclic AMP (CAMP) production and subsequent chloride efflux in response to prostaglandin E2 (PGE2) in CALU-3 bronchial epithelial cells. Thorax 2003:58(Suppl III):iii2 (abstract T4).

17 Robinson GV, Hansen PC, Miall RC, et al. Visual motion detection is impaired following total sleep deprivation in normal subjects. Thorax 2003;58(Suppl III):iii2 (abstract T6)

18 Schwan $M$, Cummins $C$, Weller $P$, et al. Differences in asthma prevalence in schoolchildren from different ethnic groups in inner city Birmingham. Thorax 2003:58(Suppl III):iii1 1-12 (abstract S33).

19 Saglani S, Payne DNR, McKenzie SA, et al. Relationship between parental reported wheeze, video questionnaire and bronchoscopy findings in preschool children with troublesome respiratory symptoms. Thorax 2003;58(Suppl III):iii 12 (abstract S34).

20 Panickar JR, Dodd SR, Smyth RL, et al. Trends in paediatric respiratory deaths in England and Wales from 1968 to 2000. Thorax 2003;58(Suppl III):iii 1 (abstract S32).

21 Shaw TJ, Sones JL, Wilson SJ, et al. Airway wall thickness in asthma and its relationship to bronchial hyperresponsiveness. Thorax 2003;58(Suppl III):iii4 (abstract S6).

22 Shaw TJ, Mehta RL, Wilson SJ, et al. Endobronchial ultrasound in the assessment of airway wall thickness. Thorax 2003;58(Suppl III):iii4 (abstract S7).

23 Reinhardt AK, Bottoms SE, Laurent GJ, et al. Evidence of a direct role for TGF$\beta 1$ in sub-epithelial airway remodelling. Thorax 2003;58(Suppl III):iii5 (abstract S10).

24 McGowan J. Health education in asthma management - does the Buteyko Institute method make a difference? Thorax 2003;58(Suppl III):iii28 (abstract S92).

25 Stirrat AK, Warren PM, MacGregor G, et al. Perception of external resistance loads in patients with hyperventilation syndrome. Thorax 2003;58(Suppl III): iii28 (abstract S93).

26 Highfield J, Searle Y, Ayres JG. Psychological morbidity and quality of life in type 1 and type 2 brittle asthma, and in severe, non-brittle asthma. Thorax 2003;58(Suppl III):iii29 (abstract S94).

27 Barber CM, Bradshaw $L M$, Curran AD, et al. Bakers cough before they wheeze. Thorax 2003;58(Suppl III):iii38 (abstract S127).

28 Sharkey RA, Daly JG, Doherty M, et al. The x-ray department and the prompt diagnosis of lung cancer. Thorax 2003;58(Suppl III):iii49 (abstract P28).

29 Dehmeshki J, Valdivieso-Casique M, Abaei M, et al. Computer assisted detection of pulmonary nodules on thoracic $\mathrm{CT}$ scans using image processing and classification techniques. Thorax 2003;58(Suppl III):iii37 (abstract S122).

30 Ohri CM, Stanley RA, Peake MD. Symptoms do not predict lung cancer diagnosis in patients referred via the two week wait process. Thorax 2003:58(Suppl III):iii 13-14 (abstract S40).

31 Le Jeune IR, Lewis NR, Baldwin DR. Presenting symptoms and chest radiographic features in urgent referrals for suspected lung cancer: how well do they discriminate? Thorax 2003;58(Suppl III):iii48 (abstract P27).

32 Stanley RA, Ohri CM, Entwisle JE, et al. Is bronchoscopy over-utilised in the diagnosis of lung cancer? Thorax 2003:58(Suppl III):iii 4 (abstract S41).

33 Tomlinson GS, Church AC, Stevenson RD, et al. Improvement in diagnostic efficiency attributable to ward-based ultrasound guided fine needle aspirate of peripheral lung lesions. Thorax 2003;58(Suppl III):iii49 (abstract P31)

34 Shotton SH, Thickett KM, Sinha B, et al. Trucut pleural biopsy is superior to Abrams'- even without radiological guidance. Thorax 2003;58(Suppl III):iii32 (abstract S106).

35 Kumaran M, Entwisle J, Vaidhyanath R. Ultrasound guided supraclavicular lymph node FNA in staging and diagnosis of patients with lung cancer. Thorax 2003;58(Suppl III):iii50-51 (abstract P35).

36 Tam W, George J, Booth H, et al. Endoscopic ultrasound (EUS)-guided fine needle aspiration (FNA) and trucut needle biopsy (TNB) in the diagnosis of mediastinal lesions. Thorax 2003;58(Suppl III):iii50 (abstract P33).

37 West SD, Slade MG. Transbronchial needle aspiration in lung cancer: no prior experience required. Thorax 2003;58(Suppl III):iii59 (abstract P67).

38 Win T, Laroche CM, Groves AM, et al. CT screening for cerebral metastases in patients with potentially resectable non-small cell lung cancer. Thorax 2003;58(Suppl III):iii49 (abstract P29).

39 Nathan J, Win T, Magee L, et al. Are lung cancer patients who are suitable for surgical resection meeting the national targets? An audit at Papworth Hospital. Thorax 2003;58(Suppl III):iiil 4 (abstract S42).

40 Eraut D. BTS survey of chemotherapy administration for lung cancer. Thorax 2003:58(Suppl III):iii5 (abstract S11).

41 Maguire J, Kelly V, Smith N, et al. Chemotherapy and radical radiotherapy for patients with inoperable NSCLC aged 70 and over: results of a treatment policy based on stage performance status at presentation. Thorax 2003:58(Suppl III): iiii5-6 (abstract S12).

42 Al-Aloul M, Alapati S, Mclver A, et al. Surgery for multifocal lung cancer. Thorax 2003;58(Suppl III):iii25 (abstract S82). 
43 Patel BD Jakes RW Welch AA et al. Are smokers with low plasma vitamin C levels at particular risk of COPD? Thorax 2003;58(Suppl III):iii 10 (abstract S28). 44 White AJ, Bayley D, Parr DG, et al. The relationship of bronchial inflammation to disease progression in COPD. Thorax 2003;58(Suppl III):iii10 (abstract S26).

45 White AJ, Parr DG, Guest PJ, et al. CT densitometry in the assessment of COPD progression. Thorax 2003;58(Suppl III):iii72 (abstract P114).

46 Mallia P, Kebadze T, Johnston SL. An experimental model of respiratory virusinduced COPD exacerbation: a pilot study. Thorax 2003;58(Suppl III):iii34 (abstract $\mathrm{S} 113$ ).

47 Allenby M, Greenaway S, Ratoff J, et al. Inhalation challenge with low dose lipopolysaccharide is safe and well tolerated on healthy subjects. Thorax 2003:58(Suppl III):iii86-87 (abstract P164)

48 Allenby M. Greenaway S, Ratoff J, et al. Sputum inflammatory profile 2 and 6 hours following low dose lipopolysaccharide (LPS) inhalation in healthy subjects. Thorax 2003;58(Suppl III):iii87-88 (abstract P167).

49 Wilkinson TMA, Donaldson GC, Hurst JR, et al. Benefits of early treatment on outcome of COPD exacerbations. Thorax 2003;58(Suppl III):iii74 (abstract P120).

50 Campbell IA, Lewis KE, Preston LA. Surveys and assessment of secondary care smoking cessation services in the UK, 2001-2003. Thorax 2003;58(Suppl III):iii42-43 (abstract P4).

51 Kaul S, Stell I, Polkey M, et al. Acute NIV in the UK: a national survey. Thorax 2003;58(Suppl III):iii22-23 (abstract S72).

52 Green AJ, Morgan MDL. The British Lung Foundation and British Thoracic Society survey of the provision of pulmonary rehabilitation in the UK, 2002 Thorax 2003;58(Suppl III):iii75 (abstract P126).

53 Sander CR, Mak V. Provision and training in non-invasive ventilation (a nationwide survey of respiratory SpRs). Thorax 2003;58(Suppl III):iii53 (abstract P46).

54 Williams A. Adjunct modafinil improves excessive sleepiness in obstructive sleep apnea: a 12-month open-label extension study. Thorax 2003;58(Suppl III): iii7 (abstract S17).

55 Morrish E, Pilsworth SN, Shneerson JM, et al. The effect of gender on mortality in treated OSA patients. Thorax 2003;58(Suppl III):iiii (abstract S19).

56 Vazir A, Kostikas K, Minnion RH, et al. Subjective sleepiness in heart failure patients with sleep disordered breathing compared to controls. Thorax 2003;58(Suppl III):iii7 (abstract S18).
57 Vazir A, Minnion RH, Dayer M, et al. Night to night variation in apnea and hypopnea index in patients with established congestive heart failure and recently diagnosed sleep disordered breathing. Thorax 2003;58(Suppl III):iii8 (abstract S20).

58 Hack M, Pickering J, Hughes J, et al. Sleep and vascular disease in the Caerphilly cohort of older men - preliminary results. Thorax 2003;58(Suppl III): iii79-80 (abstract P140).

59 Richard B, Williams EM, Prathibha BV. Obstructive sleep apnoea in stroke patients in North Gwent - prevalence and effect on functional outcome. Thorax 2003;58(Suppl III):iii80 (abstract P141).

60 Harraf F, Man W, Rafferty G, et al. Acute inspiratory and expiratory muscle weakness may contribute to increased chest infections in stroke. Thorax 2003;58(Suppl III):iii78-79 (abstract P136).

61 Kinali M, Mercuri E, Gibson BE, et al. UK physicians' attitudes and practises in long term non-invasive ventilation of children with Duchenne muscular dystrophy. Thorax 2003;58(Suppl III):iii79 (abstract P138).

62 Turner L, Watson L, Lim WS, et al. Pathogenesis of acute respiratory infections in patients on home non-invasive ventilation. Thorax 2003;58(Suppl III):iii78 (abstract P134).

63 Hopkinson NS, Nickol AH, Payne J, et al. ACE gene deletion protects against quadriceps weakness in COPD. Thorax 2003;58(Suppl III):iii79 (abstract P137).

64 Fuld JP, Kilduff LP, Neder JA, et al. A double-blind, placebo-controlled trial of creatine supplementation in patients with COPD. Thorax 2003;58(Suppl III):iii79 (abstract P139).

65 Hayee BH, Horwood N, Hughes JA. Long-term methotrexate and pulmonary function studies. Thorax 2003;58(Suppl III):iii23-24 (abstract S75).

66 Ismail T, McSharry C, Boyd F, et al. Increasing trend for immune sensitisation among pigeon fanciers over a 12-year period. Thorax 2003;58(Suppl III):iii24 (abstract S76).

67 Rutherford RM, Fisher AJ, Dark JH, et al. Functional status of 10 year survivors after lung transplantation. Thorax 2003:58(Suppl III):iii24 (abstract S77).

68 Ho LP, Urban BC, Thickett D, et al. Deficiency of CDID restricted NKT cells may contribute to dysregulated T cell proliferation in sarcoidosis. Thorax 2003;58(Suppl III):iii24 (abstract S79).

69 Partridge MR, Rippon I, Lewison G. Who funds UK respiratory research? Thorax 2003;58(Suppl III):iii22 (abstract S69).

\section{LUNG ALERT}

\section{Are obese children at risk of sleep disordered breathing?}

$\Delta$ Wing YK, Hui SH, Pak WM, et al. A controlled study of sleep related disordered breathing in obese children. Arch Dis Child 2003:88:1043-7

$\mathrm{T}$ his study tested the hypothesis that obese children are at greater risk of sleep disordered breathing (SDB) than children of normal weight, and that the risk is potentiated by pharyngeal tissue enlargement. 46 obese children (mean (SD) age 10.8 (2.3) years; BMI $27.4(5.1) \mathrm{kg} / \mathrm{m}^{2}$ ) and $44 \mathrm{sex}$ and age matched children of normal weight (BMI 18 (1.8) kg/ $\mathrm{m}^{2}$ ) were recruited to a case-control study. Children with known clinical conditions other than obesity were excluded. Two consecutive overnight polysomnographic studies were followed by a daytime multiple sleep latency test, and the size of the upper airway tissues was graded from 0 to 4 by an ENT surgeon. Obstructive apnoea (OA) was defined as the absence of airflow with persistent respiratory effort lasting longer than two baseline breaths (irrespective of $\mathrm{SaO}_{2}$ changes), and the obstructive apnoea index (OAI) was defined as the number of OA per hour of sleep. Using an OAI of $>1$ to define SDB, 12 obese children $(26.1 \%)$ and only one of the normal weight controls $(2.3 \%)$ had SDB $(p=0.002)$. SDB was related to a tonsillar size of $>2$.

The study concluded that the presence of enlarged pharyngeal lymphoid tissue in an obese child should raise the suspicion of SDB, and goes on to suggest an aggressive approach using surgical intervention. Interestingly, the sleep fragmentation and oxygen desaturation seen with SDB were not sufficient to cause an increase in daytime sleepiness and, since only six obese children had tonsils graded $>2$, further interventional studies would be needed before surgery could be confidently recommended.

D Shaw

Clinical Research Fellow, Glenfield Hospital, Leicester, UK Dominic.Shaw@uhl-tr.nhs.uk 